\title{
Leptin increases in vivo GH responses to GHRH and GH-releasing peptide- 6 in food-deprived rats
}

\author{
E Carro $^{1}$, L M Seoane ${ }^{1}$, R Señaris ${ }^{1}$, F F Casanueva ${ }^{2}$ and C Dieguez ${ }^{1}$ \\ Department of ${ }^{1}$ Physiology and ${ }^{2}$ Medicine, Endocrine Area Complejo Hospitalario Universitario de Santiago, University of Santiago, \\ Santiago de Compostela, Spain \\ (Correspondence should be addressed to C Dieguez, PO Box 563, 15780 Santiago de Compostela, Spain)
}

\begin{abstract}
Background: Leptin has recently been shown to have a stimulatory effect on basal GH secretion. However, the mechanisms by which leptin exert this effect are not yet clear. GHRH and GH-releasing peptide (GHRP)-6 are the two most potent GH secretagogues described to date.

Objective: To determine if leptin could also enhance in vivo GH responses to a maximal dose of GHRH. Design: Leptin (10 $\mu$ g i.c.v.) or vehicle was administered at random before GHRH $(10 \mu \mathrm{g} / \mathrm{kg} \mathrm{i}, \mathrm{v}$.$) or$ GHRP-6 ( $50 \mu \mathrm{g} / \mathrm{kg}$ i.v.), to freely-moving rats with food available ad libitum and to ( $48 \mathrm{~h}$ ) food-deprived rats.

Methods: Leptin and GH concentrations were measured by radioimmunoassay. Comparison between the different groups was assessed by the Mann-Whitney test.

Results: In comparison with fed rats, food-deprived rats showed a marked decrease in GH responses to GHRH as assessed by the area under the curve $(5492 \pm 190 \mathrm{ng} / \mathrm{ml}$ in fed rats and $1940 \pm 128 \mathrm{ng} / \mathrm{ml}$ in fasted rats; $P<0.05)$ and GHRP-6 $(3695 \pm 450$ in fed rats and $1432 \pm 229$ in fasted rats; $P<0.05)$. In comparison with its effects in vehicle-treated rats, leptin administered to food-deprived rats markedly increased GH responses to both GHRH $(6625 \pm 613 \mathrm{ng} / \mathrm{ml} ; P<0.05)$ and GHRP-6 $(5862 \pm 441 \mathrm{ng} / \mathrm{ml} ; P<0.05)$.

Conclusions: These data suggest that the blunted GH response to GHRH and GHRP-6 in food-deprived rats is a functional and reversible state, and that the decreased leptin concentrations could be the primary defect responsible for the altered GH secretion in food-deprived rats.
\end{abstract}

European Journal of Endocrinology 142 66-70

\section{Introduction}

In addition to stimulating body growth, growth hormone $(\mathrm{GH})$ has an important role in metabolism. In turn, alterations in nutritional status, such as obesity or food deprivation, markedly influence GH secretion. As GH secretion is normalized after weight loss in obesity or after refeeding in states of food deprivation, there is no doubt that altered $\mathrm{GH}$ secretion develops as a consequence of altered metabolic status $(1-3)$.

The $o b$ gene is an adipocyte-specific gene that encodes leptin, a protein that regulates body weight (4-8). Recent data have clearly shown that the amount of leptin mRNA in adipocytes correlates with body weight $(9,10)$. Furthermore, serum immunoreactive leptin concentrations show a strong positive correlation with body fat, being increased in obesity and decreased in anorexia nervosa $(6,9,11)$. Although the mechanisms by which leptin act are far from being understood, the presence of leptin receptors suggests that the brain is one of the main loci of the action of leptin. In addition, the recent demonstration of leptin receptors in some specific hypothalamic nuclei such as the ventromedial, arcuate, paraventricular and periventricular, provides a basis for a neuroendocrine role of leptin in the control of anterior pituitary hormone secretion (12-16).

Other recent data suggest that leptin is a metabolic signal that regulates GH secretion, as the administration of leptin antiserum led to a decrease in spontaneous $\mathrm{GH}$ secretion, whereas administration of leptin to fooddeprived rats reversed the inhibitory effect of fasting on basal GH secretion (17). However, the mechanisms by which leptin influences GH secretion are poorly understood. Thus, whereas some data suggest that leptin stimulates GH secretion by acting at the hypothalamic level regulating GH-releasing hormone (GHRH) and somatostatin-producing neurones via neuropeptide $\mathrm{Y}$ $(18-22)$, others have reported an inhibitory effect of leptin on GHRH-stimulated GH secretion from the ovine pituitary gland (23).

GHRH and GH-releasing peptide (GHRP)- 6 are the most potent $\mathrm{GH}$ secretagogues described to date. The stimulatory effect of GHRH is exerted directly at the pituitary level, whereas GHRP- 6 acts mostly in the 
hypothalamus (24-26). In order to gain further insight into the mechanisms by which leptin exerts its effects, we assessed the effect of leptin on $\mathrm{GH}$ responses to GHRH and to GHRP-6.

\section{Methods}

\section{Animals and experimental procedure}

Adult male Sprague-Dawley rats (200-250g) were housed in a 12-h light:12-h darkness cycle in a temperature- and humidity-controlled room. Chronic i.c.v. and intracardiac cannulae were implanted with the animal under sodium pentobarbitone $(50 \mathrm{mg} / \mathrm{kg}$, i.p.) anaesthesia, as described previously (27). After surgery, the animals were placed directly in isolation test chambers for 5 days and were given free access to regular Purina rat chow and tap water. Thereafter, the animals continued to have food available ad libitum or were deprived of food for $48 \mathrm{~h}$ before blood sampling. On the day of the experiment, blood samples $(0.3 \mathrm{ml})$ were withdrawn at the designated times. The animals $(n=8$ rats/group) received vehicle, recombinant leptin (supplied by Eli Lilly), or both, through the i.c.v. cannula (17). GHRH $(10 \mu \mathrm{g} / \mathrm{kg})$ and GHRP-6 $(50 \mu \mathrm{g} / \mathrm{kg})$ were administered i.v.

\section{Hormone assays}

Plasma GH concentrations were determined by doubleantibody RIA using materials supplied by the National Hormone Pituitary Program as described previously (27). Values are expressed in terms of the GH reference preparation (GH-RP-2). The intra- and interassay coefficients of variation were $7 \%$ and $10 \%$ respectively. Leptin was measured by radioimmunoassay as described previously (28). The intra- and interassay coefficients of variation were $2.4 \%$ and $4.8 \%$ respectively.

\section{Statistical analysis}

Data are expressed as means \pm S.E.M. Comparison between the different groups was assessed by the Mann-Whitney test.

\section{Results}

Basal leptin concentrations were reduced in fooddeprived rats $(0.5 \pm 0.02 \mu \mathrm{g} / \mathrm{l})$ compared with those in rats that had food available ad libitum $(1.56 \pm 0.1 \mu \mathrm{g} / \mathrm{l}$; $P<0.001)$. In fed rats, the administration of either GHRH or GHRP-6 led to a marked increase in plasma GH concentrations, as assessed by mean peak values (to $390 \pm 14 \mathrm{ng} / \mathrm{ml}$ and $250 \pm 23 \mathrm{ng} / \mathrm{ml}$, respectively; Fig. 1). The administration of leptin $45 \mathrm{~min}$ before GHRH or GHRP-6 did not modify the mean peak GH response to either peptide $(253 \pm 54 \mathrm{ng} / \mathrm{ml}$ and $220 \pm$ $19 \mathrm{ng} / \mathrm{ml}$ respectively) in these groups of fed rats (Fig. 1).

\section{FED}
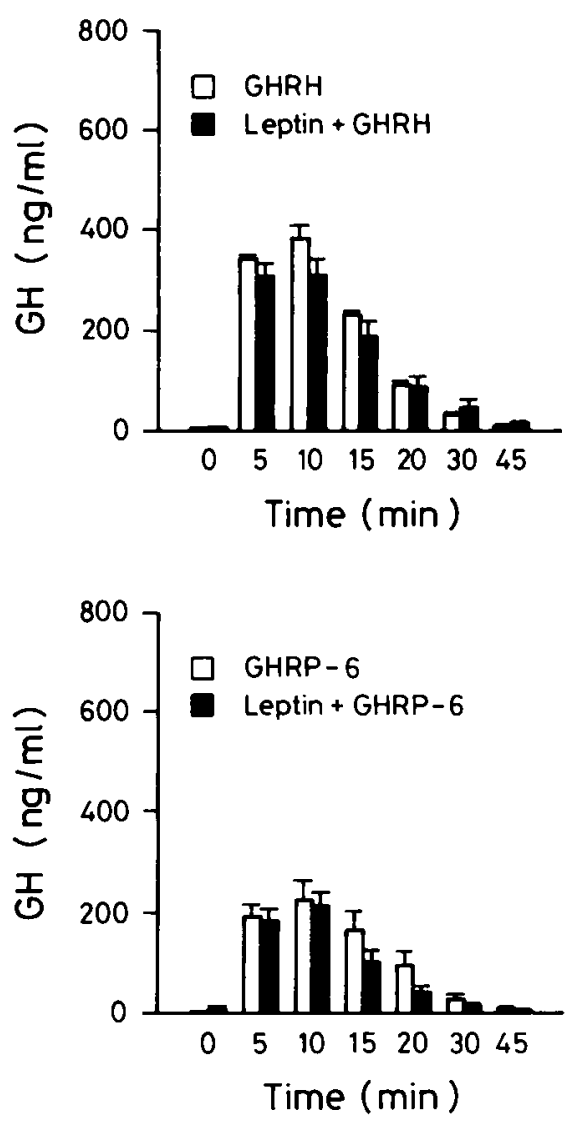

Figure 1 Serum GH concentrations (means \pm S.E.M.) in normally fed rats ( $n=8$ per group) that received either vehicle (10 $\mu$ l i.c.v., $\square)$ or leptin $(10 \mu \mathrm{g}$ i.c.v., $\mathbf{\square}) 45 \mathrm{~min}$ before the administration of $\mathrm{GHRH}(10 \mu \mathrm{g} / \mathrm{kg}$ administered i.v. at $0 \mathrm{~min})$ or GHRP-6 $(50 \mu \mathrm{g} / \mathrm{kg}$ administered i.v. at $0 \mathrm{~min})$.

In contrast, the mean peak GH response was notably reduced in food-deprived animals after administration of either GHRH or GHRP-6 $(128 \pm 12 \mathrm{ng} / \mathrm{ml}$ and $105 \mathrm{ng} / \mathrm{ml}$ respectively; both $P<0.05)$ in comparison with that in rats with food available ad libitum (Fig. 2). Interestingly, in these groups of fasted rats, the GH responses to both GHRH and GHRP-6 were markedly increased when leptin was administered $45 \mathrm{~min}$ before these secretagogues $(\mathrm{GH}$ concentrations respectively $430 \pm 23 \mathrm{ng} / \mathrm{ml}$ and $381 \pm 17 \mathrm{ng} / \mathrm{ml}$; both $P<0.05$ compared with rats treated with vehicle).

These effects were also apparent when expressed as area under the curve (Fig. 3, which also summarizes the mean peak effects).

\section{Discussion}

Although contradictory findings $(29,30)$ have been reported regarding the effect of prolonged $(72 \mathrm{~h})$ food 
FASTED
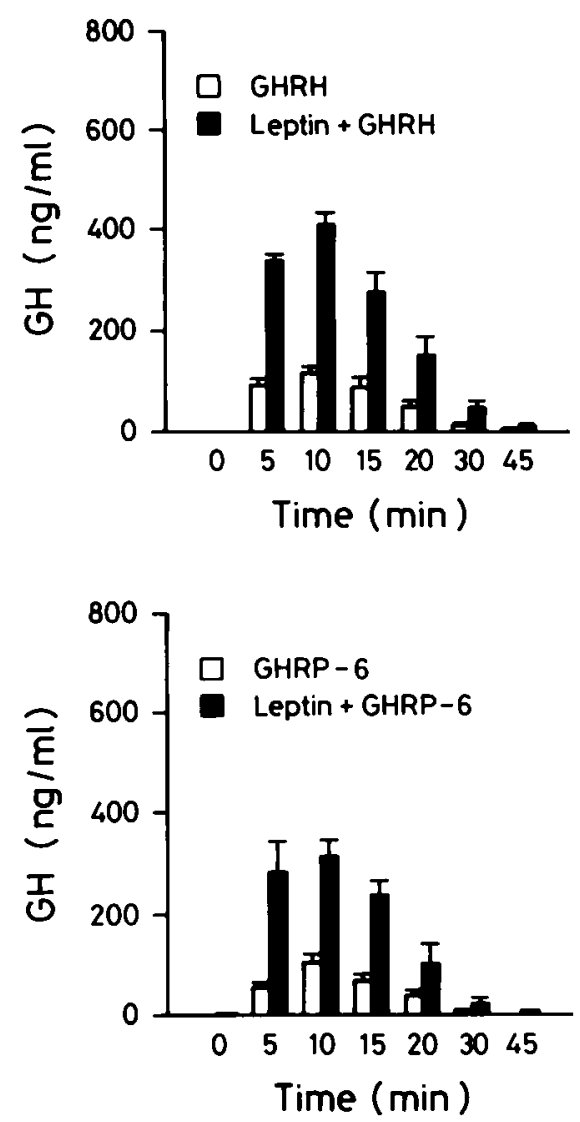

Figure 2 Serum $\mathrm{GH}$ concentrations in ( $48 \mathrm{~h}$ ) food-deprived rats (means \pm S.E.M.; $n=8$ per group) that received either vehicle $(10 \mu \mathrm{l}$ i.c.v., $\square$ ) or leptin (10 $\mu$ g i.c.v., $\square) 45 \mathrm{~min}$ before the administration of GHRH (10 $\mu \mathrm{g} / \mathrm{kg}$ administered i.v. at $0 \mathrm{~min})$ or GHRP-6 (50 $\mu \mathrm{g} / \mathrm{kg}$ administered i.v. at $0 \mathrm{~min})$.

deprivation on GH responses to GHRH in the rat, there is a general agreement that it elicits a marked decrease in spontaneous $\mathrm{GH}$ secretion $(17,29,31,32)$. This later effect is due to a suppression of high-amplitude GH secretory bursts and a decrease in the duration of secretory episodes (31). Although the mechanisms mediating these alterations remain unclear, several possibilities have been put forward. Increased somatostatinergic tone has been implicated, because passive immunization of food-deprived rats with somatostatin antiserum restored spontaneous $\mathrm{GH}$ secretion to values similar to those in normally fed rats (31). Nevertheless, hypothalamic prepro-somatostatin mRNA levels and peptide content did not differ between food-deprived and control rats, and somatostatin immunostaining in middle and caudal regions of the median eminence has been reported to be decreased $(33,34)$. The finding that food deprivation led to decreased hypothalamic GHRH concentrations, reduced prepro-GHRH mRNA

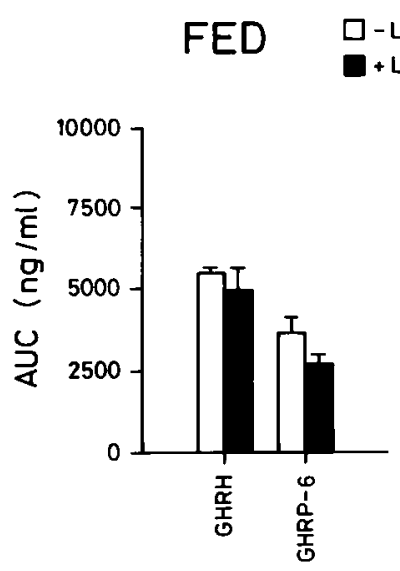

$\square$ - Leptin
+ +Leptin

FASTED
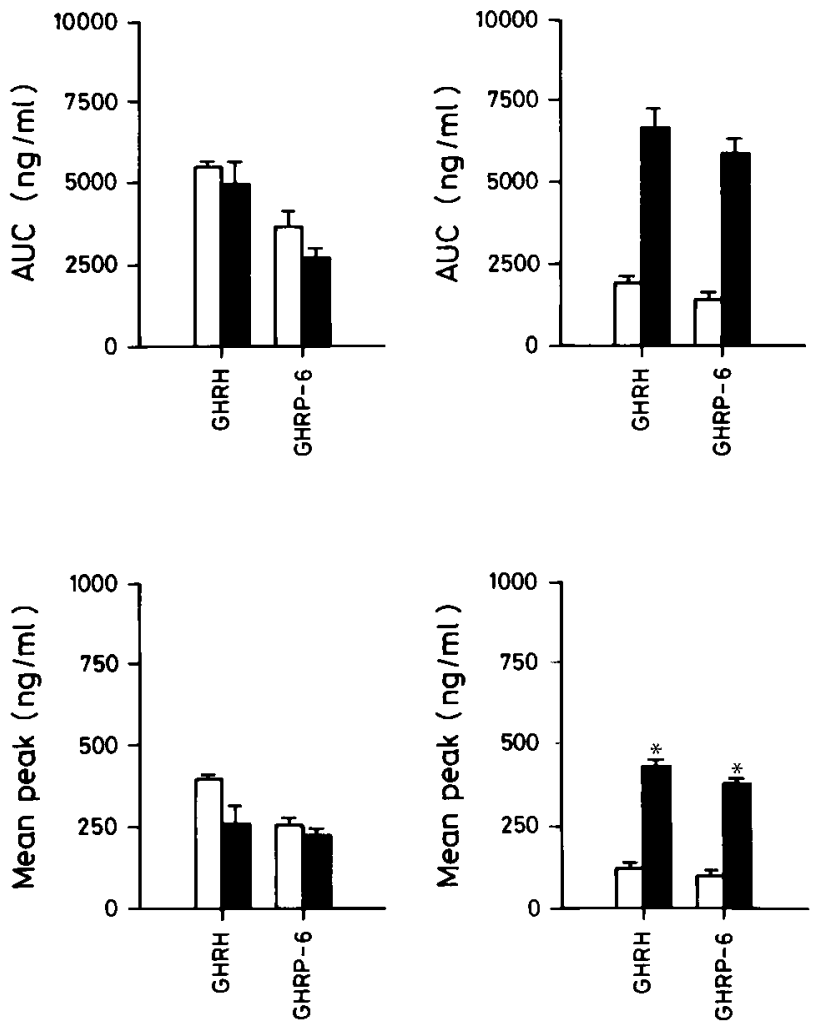

Figure 3 Mean peak GH concentrations and area under the curve (means \pm S.E.M.) in normally fed and food-deprived rats that received GHRH or GHRP-6 after the administration of either vehicle (-leptin, $\square$ ) or leptin (+leptin, $\mathbf{\square}$ ) (see also legends to Figs 1 and 2 ). ${ }^{*} P<0.05$, compared with leptin-untreated rats.

levels and decreased GHRH immunostaining in middle and rostral regions of the median eminence $(33,34)$ suggested that the marked suppression of GH secretory pulses observed in food-deprived rats could be due to decreased hypothalamic GHRH tone.

Alterations at the pituitary level are also possible. A small decrease (12\%) in GH mRNA levels has been reported in food-deprived rats (34). In addition, there is a marked decrease in somatostatin binding sites in fasted rats. Assessment of mRNA levels for the different somatostatin receptor subtypes (SSTRs 1-5) have shown a decrease (up to $80 \%$ ) in SSTR1, SSTR2 and SSTR 3 mRNA expression, whereas SSTR4 and SSTR 5 mRNA levels appeared to be unaffected in food-deprived rats compared with normally fed animals (35).

Taking into account that food deprivation is associated with a marked decrease in both plasma leptin concentrations and spontaneous GH secretion, we assessed the effect of leptin on $\mathrm{GH}$ responses to the two most potent $\mathrm{GH}$ secretagogoues, namely GHRH and GHRP-6 $(25,26)$. 
We found that, in fed rats, leptin administration did not modify in vivo $\mathrm{GH}$ responses to a maximal stimulatory dose of either GHRH and GHRP-6. These results are in agreement with previous findings of a similar ineffectiveness of leptin - acutely administered or infused for 3 days - on spontaneous GH secretion $(17,21)$, whereas central administration of leptin antiserum completely blunted episodic release of $\mathrm{GH}$ (17). Taken together, these data imply that, under normal physiological conditions, leptin is exerting a maximal stimulatory effect on GH secretion. However, it is possible that chronic sustained hyperleptinaemia - for example, as a result of infusion of leptin for 7 days - is able to increase GH secretion, even in fed rats (22).

After $48 \mathrm{~h}$ of food deprivation, GH responses to GHRH were markedly decreased compared with those in normally fed rats. Furthermore, we found that the administration of leptin 45 min before GHRH or GHRP6 completely reversed this decrease in response. These findings indicate that the blunted $\mathrm{GH}$ responses to $\mathrm{GHRH}$ induced by food deprivation reflect a functional and reversible state, and suggest that the primary alteration could be mediated by decreased leptin activation of the hypothalamic-GH axis. It is also possible that the effect of leptin in food-deprived rats could be the result of increased gene expression of the long isoform of the leptin receptor in the hypothalamus, in response to fasting (36). However, this stimulatory effect of leptin on GH responses to GHRH resembles that obtained by others who assessed the same response after passive immunization with antisomatostatin antiserum (31). As there is both direct (37) and indirect $(19,20)$ evidence suggesting that leptin could act via somatostatin, this finding was compatible with an inhibitory effect of leptin on somatostatinergic tone as the mechanism by which it enhances $\mathrm{GH}$ responses to GHRH and GHRP-6.

In summary, these data suggest that blunted $\mathrm{GH}$ responses to GHRH and GHRP-6 in food-deprived rats reflect a functional and reversible state and that decreased leptin concentrations could be the primary defect responsible for altered $\mathrm{GH}$ secretion in this experimental setting.

\section{Acknowledgements}

We would like to thank Eli Lilly for their kind gift of leptin. This work was supported by grants from Fondo de Investigacion Sanitaria, Spanish Ministry of Health and the Xunta de Galicia.

\section{References}

1 Dieguez C \& Casanueva FF. Influence of metabolic substrates and obesity on GH secretion. Trends in Endocrinology and Metabolism $1995655-59$.

2 Muller EE. Neural control of somatotropic function. Physiological Reviews 198767 962-1053.
3 Rigamonti AE, Marazzi N, Cella SG, Cattaneo L \& Muller EE. Growth hormone responses to growth hormone releasing hormone and hexarelin in fed and fasted dogs: effect of somatostatin infusion or pretreatment with somatostatin. Journal of Endocrinology $1998156341-348$.

4 Pelleymounter MA, Cullen MJ, Baker MB, Hecht R, Winters D, Boone $\mathrm{T}$ et al. Effects of the obese gene product on body weight regulation in ob/ob mice. Science 1995269 540-543.

5 Campfield LA, Smith FJ, Guisez Y, Devos R \& Burn P. Recombinant mouse $\mathrm{Ob}$ protein: evidence for a peripheral signal linking adiposity and central neural networks. Science 1995 $269546-549$.

6 Considine RV, Sinha MK, Heiman ML, Kriauciunas A, Stephens TW, Nyce MR et al. Serum immunoreactive-leptin concentrations in normal weight and obese humans. New England Journal of Medicine 1996334 292-295.

7 Halaas JL, Gajiwala KS, Maffei M, Cohen SL, Chait BT, Rabinowitz D et al. Weight-reducing effects of the plasma proteins encoded by the obese gene. Science 1995269 543-546.

8 Zhang Y, Proenca R, Maffei M, Barone M, Leopold L \& Friedmam JM. Positional cloning of the mouse obese gene and its human homologue. Nature 1994372 425-432 (Erratum Nature 374 479).

9 Hamilton BS, Paglia D, Kwan AYM \& Deitel M. Increased obese mRNA expression in omental fat cells from massively obese humans. Nature Medicine 1995 1 953-956.

10 Lonnqvist F, Arner P, Nordfors L \& Schalling M. Overexpression of the obese (ob) gene in adipose tissue of human obese subjects. Nature Medicine 19951 950-953.

11 Ferron F, Considine RV, Peino R, Lado IG, Dieguez C \& Casanueva FF. Serum leptin concentrations in patients with anorexia nervosa, bullimia nervosa and unspecific eating disorders are independent of the respective disease but correlate with the body mass index. Clinical Endocrinology 199746 289-293.

12 Couce ME, Burguera B, Parisi JE, Jensen MD \& Lloyd RV. Localization of leptin receptor in the human brain. Neuroendocrinology 199866 145-150.

13 Elmquist JK, Ahima RS, Maratos-Flier E, Flier JS \& Saper CB. Leptin activates neurons in ventrobasal hypothalamus and brainstem. Endocrinology 1997138 839-842.

14 Mercer JG, Hoggard N, Williams LM, Lawrence CB. Hannah LT, Morgan PJ et al. Coexpression of leptin receptor and preproneuropeptide $\mathrm{Y}$ mRNA in arcuate nucleus of mouse hypothalamus. Journal of Neuroendocrinology 19968 733-735.

15 Schwartz MW, Seeley RJ, Camfield A, Burn P \& Baskin DG. Identification of targets of leptin action in rat hypothalamus. Journal of Clinical Investigation 199698 1101-1106.

16 Zamorano PL, Mahesh VB, De Sevilla LM, Chorich LP, Bhat GK \& Brann DW. Expression and localization of the leptin receptor in endocrine and neuroendocrine tissues of the rat. Neuroendocrinology $199765223-228$.

17 Carro E, Señaris R, Considine RV, Casanueva FF \& Dieguez C. Regulation of in vivo growth hormone secretion by leptin. Endocrinology 1997138 2203-2206.

18 Carro E, Seoane LM, Señaris R, Considine RV, Casanueva FF \& Dieguez $\mathrm{C}$. Interaction between leptin and neuropeptide $\mathrm{Y}$ on in vivo growth hormone secretion. Neuroendocrinology 199868 187-191.

19 Carro E, Señaris RM, Seoane LM, Frohman LA, Arimura A, Casanueva FF et al. Role of growth hormone (GH)-releasing hormone and somatostatin on leptin-induced GH secretion. Neuroendocrinology 199969 13-20.

20 Cocchi D, De Gennaro Coloma V, Bonacci D, Bagnasco M \& Muller EE. Leptin regulates $\mathrm{GH}$ secretion in the rat by acting on GHRH and somatostatinergic functions. Journal of Endocrinology $199916295-99$.

21 Vaugnat B, Pierroz D, Lalaoui M, Englaro P, Pralong F, Blum W et al. Evidence for a leptin-neuropeptide $\mathrm{Y}$ axis for the regulation of growth hormone secretion in the rat. Neuroendocrinology $199867291-300$. 
22 Tannenbaum GS, Gurd W \& Lapointe M. Leptin is a potent stimulator of spontaneous pulsatile growth hormone secretion and the GH response to GH-releasing hormone. Endocrinology $19981393871-3875$.

23 Roh SG, Clarke IJ, Xu RW, Goding JW, Loneragan K \& Chen C. The in vitro effect of leptin on basal and growth hormone-releasing hormone-stimulated growth hormone secretion from the ovine pituitary gland. Neuroendocrinology 199868 361-364.

24 Ghigo E, Arvat E, Muccioli G \& Camanni F. Growth hormone releasing peptides. European Journal of Endocrinology 1997136 445-460.

25 Casanueva FF \& Dieguez C. Growth hormone secretagogues: physiological role and clinical utility. Trends in Endocrinology and Metabolism 199910 30-38.

26 Thomas GB \& Robinson ICAF. Central regulation of growth hormone secretion. In Growth Disorders, pp 99-125. Eds CJH Kelnar, MO Savage, HF Stirling \& P Saenger. London: Chapman \& Hall, 1998.

27 Mallo F, Lamas JA, Casanueva FF \& Dieguez C. Effect of retinoic acid deficiency on in vivo and in vitro $\mathrm{GH}$ responses to $\mathrm{GHRH}$ in male rats. Neuroendocrinology 199255 642-647.

28 Pinilla L, Seoane LM, Gonzalez L, Carro E, Aguilar E, Casanueva FF et al. Regulation of serum leptin levels by gonadal function in rats. European Journal of Endocrinology 1999140 468-473.

29 Wehrenberg WB, Ling N, Bohlen P, Esch F, Brazeau P \& Guillemin R. Physiological roles of somatocrinin and somatostatin in the regulation of growth hormone secretion. Biochemical and Biophysical Research Communications 1982109 562-567.

30 Tannenbaum GS, Painson JC, Lengyel AM \& Brazeau P. Paradoxical enhancement of pituitary growth hormone $(\mathrm{GH})$ responsiveness to $\mathrm{GH}$-releasing factor in the presence of high somatostatin tone. Endocrinology 1989124 1380-1388.
31 Tannenbaum GS, Rorstad O \& Brazeau P. Effect of prolonged food deprivation on the ultradian growth hormone rhythm and immunoreactive somatostatin tissue levels in the rat. Endocrinology 1978104 1733-1738.

32 Okada K, Sugihara H, Minami S \& Wakabayashi I. Effect of parenteral administration of selected nutrients and central injection of antiserum to neuropeptide $\mathrm{Y}$ on growth hormone secretory pattern in food-deprived rats. Neuroendocrinology 1993 $57678-686$.

33 Bruno JF, Olchovsky D, White J, Leidy JW, Song J \& Berelowitz M. Influence of food deprivation in the rat on hypothalamic expression of growth hormone-releasing factor and somatostatin. Endocrinology 1990127 2111-2116.

34 Brogan RS, Fife SK, Conley LK, Giustina A \& Wehrenberg WB. Effects of food deprivation on the GH axis: immunocytochemical and molecular analysis. Neuroendocrinology 199765 129-135.

35 Bruno JF, Xu Y, Song J \& Berelowitz M. Pituitary and hypothalamic somatostatin receptor subtype messenger ribonucleic acid expression in the food-deprived and diabetic rat. Endocrinology 1994135 1787-1792.

36 Bennett PA, Lindell K, Karlsson C, Robinson ICAF, Carlsson LMS \& Carlsson B. Differential expression and regulation of leptin receptor isoforms in the rat brain: effects of fasting and oestrogen. Neuroendocrinology 199867 29-36.

37 Quintela M, Señaris R, Heiman ML, Casanueva FF \& Dieguez C. Leptin inhibits in vitro hypothalamic somatostatin secretion and somatostatin mRNA levels. Endocrinology $19971385641-5644$.

Received 23 July 1999

Accepted 13 September 1999 